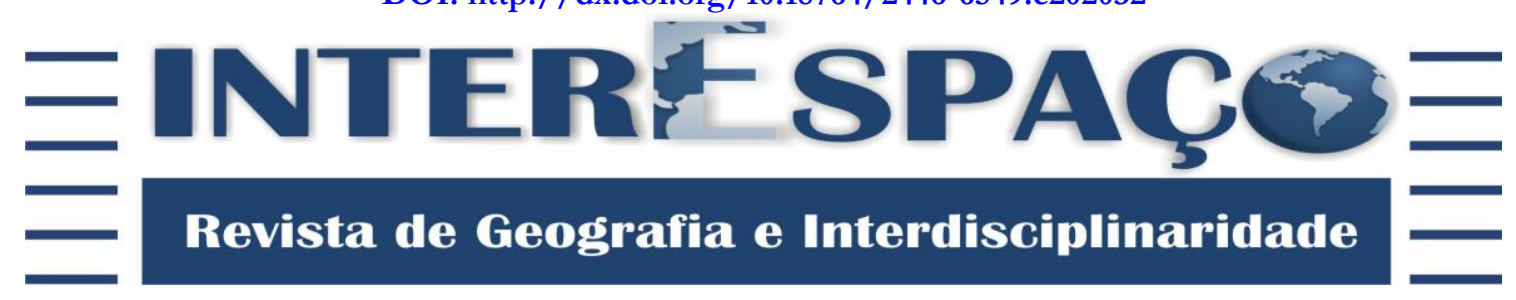

\title{
EM DIREÇÃO À CONTRA-ETNOGRAFIA
}

TOWARDS THE COUNTER-ETHNOGRAPHY

HACIA LA CONTRA-ETNOGRAFÍA

\begin{abstract}
Suelen Calonga
Mestre (MFA) em Arte Pública e Novas Estratégias Artísticas - Bauhaus-Universität Weimar. Pesquisadora em artes \& sociedade, gestora cultural e artista visual com pesquisa poética em novas estratégias, arquivos pessoais e institucionais, patrimônio cultural negro e diáspora negra. Gestora de mídia e ativos digitais na multinacional Le Creuset. calonga.suelen@gmail.com / http://orcid.org/0000-0002-6466-6077
\end{abstract}

Recebido para avaliação em 20/08/2020; Aprovado para publicação em 15/12/2020.

\section{RESUMO}

Este texto se organiza entre os assombros e os encantamentos de minhas descobertas enquanto tentava responder para mim mesma a questão "o que é o poder?". A partir da encruzilhada contida na pergunta, avancei um pouco no rumo que tomei para respondê-la, mas como é típico da pedagogia de Exu, o dono dos caminhos, todas as outras trilhas que se desdobraram a partir desta me conduziram novamente para o centro da encruzilhada: o que é o poder? Sendo a encruzilhada um lugar de possibilidades abertas, hoje me permito responder com tranquilidade que poder é o controle das narrativas; sobre si e sobre "o outro". Com base na crítica africano-centrada do pensamento e comportamento europeu (ANI, 1994) esse texto vai contar um pouco dos passos dados para essa descoberta e apontar um caminho de retomada para a autodeterminação: a contraetnografia.

Palavras-chave: Poder; Contra-etnografia; Patrimônio Cultural; Museu; Arquivo.

\section{ABSTRACT}

This text is organized between the haunts and enchantments of my discoveries while trying to answer for myself the question "what is power?". From the crossroads contained in the question, I advanced a little in the direction I took to answer it, but as is typical of the pedagogy of Eshu, the owner of the paths, all the other routes that unfolded from this one led me back to the center of the crossroads: what is power? Being the crossroads a place of open possibilities, today I allow myself to answer calmly that power is the control of narratives; about oneself and about "the other". Based on the African-centered critique of European thought and behavior (ANI, 1994), this text will tell us a little about the steps taken towards this discovery and point a way back to recover the self-determination: the counter-ethnography.

Keywords: Power; Counter-ethnography; Cultural Heritage; Museum; Archive.

\section{RESUMEN}

Este texto está organizado entre los embrujos y encantos de mis descubrimientos mientras intento responder por mí misma a la pregunta "¿qué es el poder?". Desde la encrucijada contenida en la pregunta, avancé un poco en la dirección que tomé para contestarla, pero como es típico de la pedagogía de Elegua, del dueño de los caminos, todos los demás trayectos que se desplegaron a partir de éste me llevaron de vuelta al centro de la encrucijada: ¿qué es el poder? Siendo la encrucijada un lugar de posibilidades abiertas, hoy me permito responder con tranquilidad que 
poder es el control de las narraciones; sobre uno mismo y sobre "el otro". Partiendo de la crítica africanocéntrica del pensamiento y el comportamiento europeos (ANI, 1994) este texto contará un poco los pasos dados hacia este descubrimiento y señalará un camino de vuelta a la autodeterminación: la contra-etnografía.

Palabras clave: Poder; Contra-etnografía; Patrimonio Cultural; Museo; Archivo.

31. Disse Sun Tzu: Conheça o inimigo e conheça a si mesmo; em cem batalhas você nunca estará em perigo.

32. Quando você não conhece o inimigo, mas conhece a si mesmo, suas chances de ganhar ou perder são iguais.

33. Se ignorante tanto de seu inimigo quanto de você mesmo, você tem a certeza de estar em perigo em cada batalha.

Sun Tzu, A Arte da Guerra (2006, p. 84).

\section{LONGAS INTRODUÇÕES}

Este texto se organiza entre os assombros e os encantamentos de minhas descobertas enquanto tentava responder para mim mesma a questão “o que é o poder?". A partir da encruzilhada contida na pergunta, avancei um pouco no rumo que tomei para respondê-la, mas como é típico da pedagogia do dono dos caminhos ${ }^{1}$, todas as outras trilhas que se desdobraram a partir desta me conduziram novamente para o centro da encruzilhada: o que é o poder? Como a encruzilhada é um lugar de possibilidades abertas, hoje me permito responder com mais tranquilidade que poder é o controle das narrativas; sobre si e sobre "o outro". Com base na crítica africano-centrada do pensamento e comportamento europeus de Marimba Ani (1994) esse texto vai contar um pouco dos passos dados para essa descoberta e apontar um caminho de retomada para a autodeterminação: a contra-etnografia. Cada um desses passos será tratado de forma transversal mais adiante, por isso se fazem necessárias algumas (longas) introduções.

\section{Nacionalismo Yurugu explica a branquitude}

Parto da ideia que poder é controle sobre algo ou alguém, e preciso determinar antes a quem me refiro quando falo do dominador e do dominado. De forma simples e direta, o dominador é o europeu, ou, como apontado por John R. Clarke (apud ANI, 1994, p. 15), o espírito mau da Europa. Sendo o europeu o último tronco da família humana a se juntar a essa arena que chamamos de civilização, se faz necessário que o lembremos constantemente que mais da metade da história humana já havia transcorrido quando a maioria das pessoas de África e Ásia se deram conta de que havia um europeu no mundo. Infelizmente, também faz parte do "espírito mau" europeu a ideia de que o mais jovem é

${ }^{1}$ Ver RUFINO, 2018. 
melhor que o mais velho, e o mais "moderno" é melhor que o mais antigo. Isso se refletirá desde escalas micro das relações até a geopolítica de forma geral. A arrogância, ganância e competitividade exacerbada fizeram com que europeus destruíssem mais culturas e civilizações do que construíram, e, durante os séculos XV e XVI eles não apenas lograram colonizar todo o mundo, como colonizaram também as informações sobre o mundo, desenvolvendo o monopólio de controle sobre conceitos e imagens (ANI, 1994, p. 16). "Eles estudaram pessoas sem entendê-las e interpretaram-nas sem conhecê-las", tornando a conquista da mente das pessoas africanas e asiáticas - em seus continentes originais ou em diáspora - sua maior realização (ANI, 1994, p. 17). A essa lógica europeia de supremacia e destruição, Marimba Ani chama yurugu,

\footnotetext{
um ser na mitologia Dogon que é responsável pela desordem no universo. Este é um ser concebido em negação da ordem natural, que então age para iniciar e promover a desarmonia no universo. Na Cosmologia Africana tal ser é deficiente em sensibilidade espiritual, está perpetuamente em conflito, é limitado cognitivamente e ameaça o bem estar da humanidade (ANI, 1994, p. 28).
}

Ainda segundo Ani (1994, p. 26), o "nacionalismo branco" ou o "nacionalismo europeu", entendidos aqui como o compromisso ideológico com a perpetuação, avanço e defesa de uma cultura, política, raça, e modo de vida brancos, não determinados pelo limite de um "Estado-nação", é o conjunto das formas de pensamento e comportamento Yurugu que promovem a hegemonia europeia, identificam e hierarquizam as características raciais e culturais num espectro linear que posiciona as caucasianas com superioridade e as africanas com inferioridade. Esse modo de operar no mundo leva ao imperialismo cultural, a imposição sistemática de uma cultura alheia que fratura o legado ancestral de uma população, destruindo a autodeterminação, a vontade política de um coletivo de pessoas dominadas, causando insegurança cultural. Uma das formas mais eficientes que os europeus desenvolveram para esse controle é o que Ani chama de cientificismo: um uso ideológico da ciência como "uma atividade que sanciona pensamento e comportamento, ou seja, a ciência [eurocêntrica] se torna sagrada, o mais alto padrão de moralidade" (ANI, 1994, p. 26).

\section{Objetos de arte e cultura: poder e patrimônio}

Existem muitas formas com as quais o controle de narrativa pode ser exercido, das mais violentas às mais sutis, das mais concretamente coercitivas às mais psicologicamente subjetivas. Dentre os lugares privilegiados de enunciação e atribuição de narrativas, notadamente a Academia, a Mídia, a Arte, vou optar aqui por tratar especificamente das 
narrativas apoiadas em objetos de arte e cultura, pois compreendo que desses objetos emana um precipitado de essência cultural (BAZIN apud VELTHEM, 2012) que dará sentido a articulação de ideias que apresento mais à frente.

Objetos de arte e cultura, quer sejam materiais ou imateriais, "participam de forma decisiva para a produção e a reprodução social e representam importantes mediadores para as relações que são estabelecidas entre indivíduos e grupos, no seio da coletividade (...) cuja ênfase recai, sobretudo, nas relações sociais e simbólicas" (VELTHEM, 2012). Ou seja: por serem esses objetos-meio para relações, e não objetos-fim, não é possível depositar, medir, acessar ou transferir os valores inscritos (nos objetos) sem esvaziá-los completamente do que lhes dá o valor propriamente. E aqui reside um ponto importante para entender de onde parto e o caminho que tomarei mais adiante: quais são esses significados e como se dão esses esvaziamentos a partir do acúmulo, ou arquivamento, desses objetos.

Apropriação cultural, ao contrário do que os mais recentes delírios yurugu propagam - principalmente na internet -, tem menos a ver com o cerceamento das liberdades individuais de pessoas brancas que não querem ter suas escolhas questionadas em termos de vestimentas, adornos e penteados, e mais com processos instalados de violência colonial que possibilitam, por exemplo, que artefatos centrais em práticas cotidianas, litúrgicas e seculares de grupos culturais que foram roubados permaneçam ainda hoje em posse institucionalmente legal de seus ladrões. A espoliação, despossessão e privação de acesso que os verdadeiros donos dos objetos (sejam materiais ou imateriais) sofrem no processo de (des)apropriação cultural é diretamente proporcional ao lucro simbólico e financeiro que os usurpadores adquirem ao obtê-los.

Ao acúmulo, ou arquivamento, desses objetos adquiridos, chamamos de patrimônio, herança ou legado, dependendo do tipo, e a figura (pessoa ou instituição) que o controla está sempre imbuída de muito poder. Falarei disso em mais detalhe adiante. Por vivermos imersos em um sistema que atribui e prioriza o valor econômico/financeiro a tudo, tendemos a confundir poder com dinheiro, mas ao observarmos as questões que correm no fundo das relações, percebemos que o dinheiro escoa na direção do poder, mas não são a mesma coisa. O poder atrai o dinheiro. O poder é especulativo. E ideológico. Quem é poderoso o é por ter controle sobre as relações (políticas, financeiras, coercitivas, etc.); o é porque consegue convencer os demais de que é poderoso (o controle da narrativa de si) e que "o outro" não é tão poderoso quanto ele, por isso pode/deve ser dominado (o controle da narrativa sobre o outro). E esse poder, como já foi dito anteriormente, pode ser exercido de muitas formas, pelo dinheiro, pela violência física e/ou simbólica, pela manipulação retórica, etc. 


\section{O que é um Museu, ou um Arquivo}

Para os fins da análise que farei adiante, gostaria de resguardar a licença de chamar de "Arquivo" todas as instituições que lidam com a salvaguarda, manutenção e difusão de patrimônio, herança ou legado artístico-cultural (sejam museus, arquivos em si, galerias, bibliotecas, universidades, repositórios, centros culturais, etc.). Vou chamá-las todas de Arquivo porque compreendo que a razão (moderna) de suas existências reside na articulação do exercício de poder (o controle das narrativas), em um lugar privilegiado de enunciação das narrativas controladas e acúmulo de patrimônio/herança/legado corporificado em uma instituição) que levam à capacidade de se posicionarem como "lugares de memória". Essa convergência de fatores possibilita o agenciamento das relações necessárias para o processo de construção ou destruição de uma memória coletiva, e o processo de construção ou destruição de um esquecimento coletivo. A relação entre estes lugares da memória e os procedimentos de engajamento com o passado e a "história", é, portanto, uma relação baseada em poder.

Da forma como o conhecemos hoje, o modelo francês, o Museu foi criado como uma instituição de educação, mas não no sentido do ideal de liberdade pela educação, mas no sentido de ser um lugar onde estão arquivados objetos de arte e cultura que podem ser acessados e adquiridos para que se conheça melhor o eu a partir da delimitação das diferenças percebidas no outro. Mais a frente observaremos a gênese do Museu que já desde seu mito de fundação descreve a sua motivação inicial, ainda que os interesses possam ter sido adaptados no decorrer do tempo.

Grandes mudanças na configuração política e social da Europa ocorreram após as revoluções burguesas, em particular a Revolução Francesa (1789-99) e a Revolução Industrial (1820-40), impactando todos os países do continente europeu - e, consequentemente, o mundo, através da expansão imperialista - e causando a turbulenta transição do feudalismo para o capitalismo. A burguesia consolidou sua força econômica e sua ascensão ao poder político, implementando o modelo de governança de Estado-nação para melhor servir a seus interesses a partir de uma estrutura e infraestrutura legal que facilitaria empreendimentos comerciais (internacionais) e a acumulação de capital.

A criação dos museus como instituições com o objetivo de educar a população moderna, tendo desde sua fundação a função política de controle narrativo e discurso de supremacia, ganhou uma dimensão ainda mais complexa com a melhoria do sistema capitalista, com a possibilidade de multiplicar a riqueza trabalhando em seu próprio favor: os tesouros antes intocáveis e escondidos, com acesso restrito a pouquíssimas pessoas, são 


\title{
|Suelen Calonga |
}

elevados, então, à condição de atração turística que traria pessoas de todo o mundo e geraria ainda mais relevância comercial. Então, seria um ganho de duas mãos: de um único investimento (as viagens exploratórias de etnógrafos a outras terras), o conjunto de objetos recolhidos serviria tanto para fins econômicos quanto políticos. "Vale mencionar também que a memória, objeto central dessas empresas, dá legitimidade ao projeto institucional e aos agentes sociais a ele dedicados (HEYMANN, 2005)". É por isso que os museus, hoje, competem com o turismo sobre nossa noção atual do que é "patrimônio".

\begin{abstract}
Este plano museológico merece atenção. O poder narrativo exercido amplia sua rede de relações, produz novos significados, estabelece linhas de pensamento, determina o que deve ser conhecido, multiplica as instituições da memória (e do esquecimento) atribuindo-lhes um papel de fonte de conhecimento, 'luz' e 'iluminação' (CHAGAS, 2011, p. 7).
\end{abstract}

Marlene Suano explica como a burguesia europeia organizou o conhecimento e o know-how de forma a consolidar o poder recém-adquirido: a educação seria a grande arma de domínio nos países modernos, e os museus eram muito bem adaptados às necessidades da burguesia para este fim. Na França, por exemplo, a Convenção Revolucionária Nacional aprovou em 1792 a criação de quatro museus com um objetivo explicitamente político e a serviço da nova ordem (SUANO, 1986, p. 28-29): O Museu dos Monumentos (Trocadéro) $^{2}$, construído no contexto da III Feira Mundial de Paris, em 1878; o Museu do Louvre $^{3}$ e o Museu de História Natural ${ }^{4}$, ambos lançados em 1793; e o Museu de Artes e Ofícios (des Arts et Métiers), lançado em 1794. Na esteira deste mesmo movimento social foram inaugurados aqueles que, além do Louvre, eram os maiores e mais importantes museus da Europa ${ }^{5}$ : Viena (1783), Amsterdã (1808), Madri (1819), Berlim (1810), São Petersburgo (1852) que são até hoje - embora seus nomes tenham mudado - os maiores detentores de objetos etnográficos trazidos de outros continentes. Desta forma, esta nova classe dominante buscou atuar em diferentes frentes para o estabelecimento de novas identidades nacionais, atuando fortemente nos campos cultural e artístico, mas sempre com vistas ao comércio e às finanças.

\footnotetext{
${ }^{2}$ Concebido para contar a história da França revolucionária, favorecendo o neoclassicismo e o imperialismo de Napoleão, ambos frutos da mesma ideologia de uma França que se pensava herdeira da Grécia e Roma na hegemonia da Europa (SUANO, 1986, p. 28).

${ }^{3}$ No início aberto ao público apenas três dias em cada dez, a fim de educar a nação francesa nos valores clássicos da Grécia e Roma e no que representava sua herança contemporânea: além das coleções reais, com objetos trazidos das colônias, era composto de material proveniente de igrejas saqueadas pelos revolucionários franceses e dos botins que Napoleão trouxe de outros países europeus e até do Egito (SUANO, 1986, p. 28).

${ }^{4}$ Juntamente com o de Artes e Ofícios, visando o desenvolvimento do pensamento científico.

${ }^{5}$ Embora suas coleções fossem sendo migradas e fundidas com outras ao longo do tempo, e em alguns casos as coleções originais estejam em outros museus hoje, estes edifícios ainda mantêm o mesmo status de "grandes obras" que significavam no passado.
} 


\title{
POR QUE OS ARQUIVOS ARQUIVAM?
}

\section{Zeus e Mnemosyne: um arquivo da memória, um lugar de poder}

Existem mitos fundantes para cada aspecto de todas as culturas, e como a cultura ocidental (de forma generalizada) é muito marcada pela herança grega, gostaria de recuperar uma história da tradição europeia que justifica não apenas a existência de museus como os conhecemos hoje, mas o modo de operação destas instituições que, embora tenha sido adaptado ao longo dos séculos, ainda mantém sua essência mítica:

\begin{abstract}
Zeus, deus dos deuses e grande-pai da força e da ordem, filho de Cronos (o Tempo) e Rhea (a Rainha-mãe), tinha o dom e o hábito de se disfarçar de outros seres para seduzir e enganar as pessoas, sempre movido por uma grande paixão. Se disfarçou de pássaro para atrair e enganar sua irmã Hera. Se disfarçou de cisne para seduzir Leda. Se transformou em um lindo touro branco de olhos azuis e raptou Europa para ter com ela seus filhos. Zeus se transformou até mesmo em uma chuva dourada que penetrou pelo corpo de Dânae para conceberem o famoso herói Perseu. Uma vez, ele se disfarçou de pastor e conquistou amorosamente o titã Mnemosyne (a Memória), filha de Urano (o Céu) e Gaia (a Terra). Eles ficaram juntos por nove noites, gerando suas nove filhas, as Musas, personificações das artes e das ciências, da memória e da narrativa, encarregadas de cantar as vitórias, belezas e atos divinos que fariam os humanos esquecerem a ansiedade e a tristeza e os inspirariam para grandes feitos. A casa-templo onde viviam, o Mouseion, ficava no alto do Monte Parnaso e era um lugar dedicado ao culto e à contemplação dos ofícios de cada musa: Clio, era a guardiã da história e da ciência e Calliope era a guardiã da literatura e da retórica - estas duas ficaram conhecidas como as filhas favoritas Euterpe da música e da poesia lírica; Erato dos versos eróticos; Melpomene e Thalia da tragédia e da comédia, respectivamente; Polyhymnia cuidava da música sacra e da geometria; Terpsichore do canto e da dança; Urania da astronomia e da astrologia. ${ }^{6}$
\end{abstract}

Sandra Pesavento (2003) propõe o exercício de pensarmos quais seriam hoje, no novo milênio, os atributos e perfil de Clio, a favorita das musas. Segundo a autora, estaria certamente nomeada como História Cultural.

Fisionomia serena, olhar franco, beleza incomparável. Nas mãos, o estilete da escrita, a trombeta da fama. Seu nome é Clio, a musa da História. (...) Talvez, até, Clio superasse Mnemósine, uma vez que, com o estilete da escrita, fixava em narrativa aquilo que cantava e a trombeta da fama conferia notoriedade ao que celebrava. No tempo dos homens, e não mais dos deuses, Clio foi eleita a rainha das ciências, confirmando seus atributos de registrar o passado e deter a autoridade da fala sobre fatos, homens e datas de um outro tempo, assinalando o que deve ser lembrado e celebrado (PESAVENTO, 2003, p. 7).

\footnotetext{
${ }^{6}$ Minha forma de contar o mito está livremente adaptada a partir de muitas fontes, orais e escritas (e, dentre as escritas, formais e não-formais) que recolhi lendo sites na internet, como verbetes da Wikipédia e blogs de mitologia, e conversando com conhecedores dos mitos helênicos e do panteão olímpico. Por ser uma narrativa de domínio público, tomarei a liberdade de contá-la à minha maneira, sem citar pontualmente as referências.
} 
Há muitos pontos interessantes que eu gostaria de destacar nas histórias sobre o Mouseion no Monte Parnaso, que nos ajuda a entender como o Museu possui um programa que já estava inscrito nele desde sua concepção mítica. Por exemplo, apesar de ser programado como lugar de criatividade e lazer, seu patrono foi Apolo (senhor da razão pura) e não Dionísio, seu irmão (governante da liberdade, dos jogos e do prazer). E também que Clio, musa da história e da ciência, que divulga e celebra grandes realizações, é muito evocada por ser filha de Mnemosyne, e compartilhar com sua mãe o dom de lembrar. Mas as pessoas costumam não dar muita atenção ao fato de ela também ser filha de Zeus, o Rei dos Deuses, a maior autoridade do Olimpo e dono do poder (lei e ordem); aquele com o dom da falsidade ideológica, que metamorfoseia sua voz e aparência para seduzir e enganar outras pessoas e outros deuses. Zeus é, portanto, o portador do poder, e o exerce através do controle das narrativas sobre si (ao fingir ser outra coisa) e sobre o outro (dissuadir e enganar). A História e a Ciência - Clio - habitante privilegiada do Museu (Mouseion) - retém atributos herdados de sua mãe, a Memória - mas eu gostaria de destacar que ela também se expressa à maneira de seu pai, o Poder. Para mim, esse é um aspecto que não pode ser perdido de vista. Esse é o motivo pelo qual os arquivos arquivam.

\section{O “asili” europeu expresso no método etnográfico}

Enquanto tecia minha crítica aos processos e procedimentos das Ciências Sociais para a composição do arcabouço teórico da minha dissertação de mestrado (CALONGA, 2020) tentei compreender as motivações e justificativas para a permanência, ainda hoje, de coleções institucionais da Europa que são heranças diretas do espólio, apropriação e roubo de propriedade intelectual, material e simbólica de povos que foram colonizados por nações europeias. Essas coleções, que hoje compõem os muito visitados e lucrativos museus europeus, em especial os museus etnológicos, são derivadas de coleções particulares de missionários, cientistas, militares e artistas comissionados por seus países em viagens coloniais etnográficas. Inclusive, o "pacto narcísico" (BENTO, 2002) da yurugu permitiu que, apesar das diferenças políticas entre as nações, houvesse acordos de transferência de acervos de uma nação a outra sem, contudo, se cogitar a hipótese de devolvê-los a seus proprietários originais e de direito.

O uso moderno do termo "etnologia" é creditado ao jurista e historiador Adam Franz Kollár, definido em sua Historiae ivrisqve pvblici Regni Vngariae amoenitates publicada em Viena em $1783^{7}$ como "a ciência das nações e dos povos, ou, aquele estudo dos homens instruídos no qual eles inquiriram sobre as origens, línguas, práticas e instituições de várias

${ }^{7}$ Cf.: <https://www.europeana.eu/en/item/9200332/BibliographicResource 3000095469207>. 


\section{|Suelen Calonga |}

nações, e finalmente sobre a pátria e assentos antigos, a fim de poder julgar melhor as nações e os povos em seu próprio tempo” (MANDAVILLI, 2018). Hoje, o termo é entendido como a ciência que estuda os documentos reunidos por e através da "etnografia" (esta, portanto, o método), buscando a apreciação analítica e comparativa das culturas e civilizações, em relação ao lugar de enunciação do etnógrafo. Embora seja constantemente criticado, revisto e atualizado, o desenvolvimento da etnografia ao longo do tempo acompanhou a expansão da Europa pelo mundo em suas várias dissimulações, adaptações, sutilezas e sofisticações.

No momento da tessitura da minha monografia, na qual me detive um pouco mais em torno da etnomusicologia ${ }^{8}$, pela observação de uma coleção de fonogramas, eu me deparei com a observação (que hoje me parece óbvia) de que a etnologia - e sobretudo seu método, a etnografia - são práticas endêmicas da/na/para a Europa. Logo, ao usar "povo, nação, tribo (com costumes, língua, religião), (...) para se referir a outros povos que não o próprio" (GRAEFF, 2020), o método etnográfico, em todas as suas aplicações (etnobotânica, etnomatemática, etnolinguística, etno...etc) se reduz àquilo que se usa para estudar o alheio, pressupondo, e muitas vezes exigindo, um ponto central de análise que é a visão europeia sobre o mundo. Não fosse isso verdade teríamos a possibilidade de o centro ser deslocado e, por exemplo, a "etnomusicologia seria a musicologia sobre o outro, sobre povos estrangeiros, o que no Brasil poderia significar a música, por exemplo, clássica europeia, e não a brasileira" (GRAEFF, 2020). No entanto, o prefixo etno- se aplica da Europa "para fora". Um europeu que estuda a teoria de sua própria música é um musicólogo, mas um africano que estuda a música de seu próprio povo é nomeado etnomusicólogo.

É sabido que entre os povos de Kemet (Egito antigo) já existia a prática de retratar - de forma distinta em pinturas e murais - as características de outras etnias que os rodeavam, mas foram os gregos (assumidos bebedores da fonte kemética em todas as áreas do conhecimento) e seus textos com descrições detalhadas dos "éthneos" (povos) persas e citas, assim como a geografia de seus territórios, que podemos rastrear a prática de estudar a "alteridade" sob a justificativa de colaborar para a definição de si mesmo e o controle do outro.

\footnotetext{
${ }^{8} \mathrm{Um}$ dos meus objetos de pesquisa para a dissertação foi a descoberta de uma pequena coleção de fonogramas de Candomblé que supostamente teriam sido gravados em Salvador em 1937 - uma época em que o Candomblé ainda era criminalizado - e que estão sob a custódia do Berlin Phonogramm Archiv da Alemanha, sem nenhuma identificação e/ou informação de sua proveniência. E com informações incorretas e/ou não-confirmáveis publicadas em fontes ditas "científicas". Essa descoberta me levou a realizar uma pesquisa preliminar independente e promover a restituição direta, informal e não autorizada pelo detentor "oficial" aos herdeiros morais do patrimônio: a comunidade de santo de Salvador, em 2020.
} 


\title{
|Suelen Calonga |
}

O substantivo grego éthnos ("povo") está para a Europa, a partir do Renascimento, como o termo bárbaros esteve para o mundo grego antigo. Os éthne ("povos") não são aí, desta maneira, simplesmente "povos", mas em bloco e residualmente os "outros", aqueles povos pagãos, não-cristãos (MENEZES BASTOS, 1995, p. 16).

A minha sentença dita na página anterior, de que a etnografia é uma prática endêmica da/na/para a Europa pode ser mais detalhadamente explicada pelos conceitos de Marimba Ani (1994, p. 12) para as formas de expressão do asili europeu. Para a autora, asili é o logos, o germe/semente de desenvolvimento de uma cultura. "É a essência cultural, o núcleo ideológico, a matriz de uma entidade cultural que deve ser identificada a fim de dar sentido às criações coletivas de seus membros" (p. 25); "como ferramenta conceitual de análise cultural refere-se ao princípio explicativo de uma cultura" (p. 12).

\begin{abstract}
A ideia é que o asili é como um modelo que traz dentro de si o padrão ou modelo arquetípico para o desenvolvimento cultural; poderíamos dizer que é o DNA da cultura. Ao mesmo tempo, ele encarna a "lógica" da cultura. A lógica é uma explicação de como ela funciona, bem como o princípio de seu desenvolvimento. (...) o asili gera um desenvolvimento sistemático; (...) é formulativo, e é ideológico na medida em que dá direção ao desenvolvimento. Ele é responsável pela consistência e pelo padrão da cultura, e também por sua tenacidade. O asili determina o desenvolvimento cultural; (...) É uma força convincente que orientará a cultura enquanto ela permanecer intacta: ou seja, transportada no "genes culturais". Para que a cultura possa mudar (e isto inclui o pensamento e comportamento coletivo dos que estão dentro dele), o próprio asili teria que ser alterado. Mas isto envolveria um processo de destruição e o nascimento de uma nova entidade. Asili(s) cultural(ais) não são feitos para serem modificados (ANI, 1994, p. 12).
\end{abstract}

Eu poderia afirmar que, por ser um logos, o asili europeu pode ser entendido como a Etnologia. Ou seja, a Etnologia é a semente, a lógica fundante de uma cultura que, na verdade, não conhece a si mesma, mas é capaz de descrever em detalhes tudo aquilo que não é a partir da comparação com outras. Como o asili não se autoexpressa, assim como a Etnologia, mas depende de um veículo para se viabilizar no mundo, considero essa expressão o método etnográfico. A etnografia, expressão do asili europeu, foi estabelecida pela primeira vez com a justificativa da alteridade. Depois, passou a trabalhar para a justificativa de um ideal falacioso de evolucionismo, que propunha que era necessário entender as chamadas "sociedades primitivas" - pois mais antigas - e analisar o caminho que teria sido tomado para chegar ao suposto ponto de complexidade da sociedade europeia, considerando uma linha de evolução que colocaria a Europa como mais "avançada". Na sequência, governos e outras instituições de países da Europa começaram a ver grandes oportunidades de lucro no financiamento de expedições de aventureiros, missionários religiosos e cientistas das mais diversas áreas (geologia, botânica, zoologia, antropologia, etc.) para que pudessem coletar relatórios, objetos, amostras de 
biodiversidade, minerais, fauna, flora, e muitas vezes até mesmo indivíduos dos povos dos territórios. A descrição detalhada do modo de vida, práticas, comportamentos, valores, crenças e regras sociais de outros povos rapidamente se provou eficiente para os objetivos colonizatórios europeus. Seria mais fácil conquistar, dominar, explorar outro território quanto melhor se conhecesse os detalhes da formação sociocultural das pessoas que o ocupavam.

As coleções derivadas destes sortimentos eram compostas de objetos exotização de "pessoas de terras distantes" - que ao chegarem na Europa compuseram mostras de aberrações, zoológicos humanos ou os tão famosos Gabinetes de Curiosidades que originaram muitos dos museus etnológicos existentes hoje principalmente na Inglaterra, França, Holanda e Alemanha - mas também troféus de batalhas que se tornam tesouros governamentais: souvenires das guerras coloniais, coletados e expostos pelo mesmo motivo que um caçador exibe em sua sala a cabeça de um veado que ele abateu na floresta: porque essa é uma expressão genuína do asili europeu.

\section{O poder do legado: academicismo, universalismo e a ciência como religião Yurugu}

Em português, a noção de legado por vezes se confunde com a de herança, são muito próximas em significado. Herança é melhor entendida como algo herdado por direito ou por atribuição, normalmente de cunho material, enquanto legado é um lastro simbólico que se passa de uma geração a outra e/ou que se projeta para a posteridade, de forma coletiva ${ }^{9}$. Legado pode ser entendido como uma declaração pública de poder simbólico.

Marimba Ani, ao tratar do legado do nacionalismo europeu, apresenta o "universalismo" da Era Vitoriana (1837-1901), que, dentro da visão de mundo europeia, "representaria um estado moral mais objetivo, com a suposição de que os valores europeus foram alcançados 'criticamente' e 'racionalmente' e que seriam, portanto, universalmente válidos" (ANI, 1994, p. 55) como um legado do Iluminismo. Um outro legado do nacionalismo europeu identificado por Ani é o imperialismo cultural-científico institucionalizado na Academia. A transformação, inaugurada por Platão, da "epistemologia em ideologia” (p. 104), que, por ter se arrastado por séculos nos quais o estilo cognitivo europeu se tornou uma extensão do Platonismo, fez com que "não apenas todos os intelectuais europeus, mas todos os intelectuais fossem treinados na academia" porque esse

\footnotetext{
9 O dicionário Michaelis aponta essa definição como uma forma figurativa da palavra legado, enquanto a forma jurídica seria um benefício patrimonial disposto de uma pessoa a outra, ou ainda a "parte da herança deixada pelo testador a quem não seja herdeiro por disposição testamentária nem fideicomissário. $<\underline{\text { http://michaelis.uol.com.br/moderno-portugues/busca/portugues-brasileiro/legado/>. }}$.
} 


\section{|Suelen Calonga |}

é o legado de Platão, e, hoje, uma prova do sucesso do imperialismo cultural-científico europeu. "A Academia preservou uma tradição cultural, uma raça de povos e uma sociedade dominante. Não importa quais sejam as controvérsias inter-relacionadas e chamadas revoluções políticas que possam ocorrer, a Academia garante que a infraestrutura ideológica permanecerá intacta” (ANI, 1994, p. 105), sendo um dos pilares que sustenta essa infraestrutura, a própria restrição ao seu acesso.

O universalismo e o academicismo confluem para a institucionalização das ciências, em especial as Ciências Sociais, na passagem do século XVIII para o XIX, que cancelou o mítico e estreito diálogo anterior entre História e Literatura no mundo ocidental, consolidando a hierarquia entre a representação de um suposto real (racional, universal, lógico e objetivo) por sobre a representação de um possivel - ou a passagem da imaginação para a imagem ${ }^{10}$. A separação e hierarquização das Ciências Sociais das/sobre as Humanidades (não consideradas ciências) por uma suposta maior preocupação e rigor metodológicos, colocou a História (Clio) no lugar da consolidação de uma nova compreensão de civilização, construída através da sucessão de "fatos" documentados, ao invés do lirismo de "contar histórias" (Calliope), mesmo que este último fosse muitas vezes não-ficcional. Isso é importante porque o atestado de "fato" passa a ser um documento construído para esse fim, não mais apenas um testemunho: a palavra escrita passa a valer mais do que a palavra oral. Mesmo considerando a possibilidade de falsificação de um documento, essa concretização do atestado do fato ainda teria maior relevância como prova de um evento. E assim se produz conhecimento no asili europeu: através da acumulação desses documentos em arquivos, bibliotecas, museus, etc., para que sejam acessados. Já volto nesse ponto.

É importante ressaltar e fazer um contraponto aqui, que em outros asili a transmissão do conhecimento se dá através de um paradigma multidisciplinar que cruza diferentes atividades e práticas culturais, como apresentado por Kazadi wa Mukuna (2018) sobre o sistema africano de conhecimento, que inclui a tradição oral como um modo de registro. Isto significa que não é porque o conhecimento não está gravado em um suporte material (documento, objeto), que ele não é concreto ou que não está registrado. Mais recentemente essa noção tem sido reconhecida no Ocidente sob o termo patrimônio cultural intangivel, embora ainda não seja verdadeiramente aceita como um sistema legítimo de produção de conhecimento porque não encontra referenciais nos modelos científicos academicistas e universalistas yurugu. Em defesa da tradição oral no debate entre tradição

\footnotetext{
10 Para mais insights em torno da passagem da imaginação para a imagem, exemplos de transmissão de conceitos sobre imagens e imaginação, a utilização das imagens visando mobilizar o dinamismo psíquico dos destinatários em práticas culturais do Brasil colonial e práticas acerca da ordenação da imaginação e do uso das imagens na Idade Média e na Idade Moderna no Ocidente e no Brasil colonial, ver MASSIMI, 2012.
} 
escrita e conhecimento verbal, o autor malinês Hampaté Bâ apresenta a diferença entre as duas epistemologias: "A escrita é uma coisa e o conhecimento é outra. A escrita é a fotografia do conhecimento, mas não é o conhecimento em si. O conhecimento é uma luz que está no homem” (HAMPATÉ BÂ, 1981 apud MUKUNA 2018).

As importantes mudanças na subjetividade que surgiram no século XIX, desde o paradigma das imagens técnicas (FLUSSER, 1985; SANTAELLA \& NÖTH, 1998), ou seja, imagens produzidas com a mediação das máquinas inventadas na época, como a fotografia, permitiram que a compilação da memória coletiva no Ocidente partisse da premissa de uma suposta objetividade dos fatos, que se encontrava em documentos, sinônimos de prova de verdade (ROUILLÉ, 2009). Com isto, os historiadores europeus começaram a se chamar "cientistas" em um século marcado pela ciência, e não mais como contadores de histórias. A criação e o acúmulo de documentos, especialmente visuais, quer por palavra ou imagem, representavam a busca desta chamada história científica, ou melhor, uma ciência composta de fatos históricos. A primazia do registrado sobre o vivido. Além disso, o século XIX também marcou a profissionalização da prática historiográfica, impulsionada por historiadores positivistas - principalmente através da figura de Leopold Von Ranke na Alemanha - que propuseram a crítica de fontes escritas guiadas por uma busca da verdade. Como resultado, a história efetivamente rompeu com a arte literária para se transformar e consolidar como uma disciplina acadêmica ensinada nas universidades alemãs. Durante este período, as pessoas que escreviam história procuravam distinguir claramente seus discursos das narrativas literárias (GONÇALVES, 2014).

Por outro lado, Kazadi (MUKUNA, 2020) nos instrui sobre o papel dos historiadores em outros asili, por exemplo entre os povos Mandingo e Bambara (Mali), nos quais não existe a possibilidade de fraude na narração de um fato, pois ele está registrado e documentado no corpo de uma pessoa ancestralmente designada a este fim: a casta nyamakala é composta de pessoas que herdam (hereditariamente) a capacidade de carregar e transmitir a força viva presente nos objetos animados e inanimados, e é dividida entre artesãos (ferreiros; sapateiros e trabalhadores de couro; tecelões; madeireiros, etc.) e mestres da palavra e da música, chamados jali (griots). Mas ser um jali significa não só poder contar histórias e tocar instrumentos, mas também executar

várias responsabilidades na corte real, que incluíam, mas não se limitavam a ser historiador e genealogista, compositores de épicos e canções que glorificavam as grandes façanhas do rei e dos membros da aristocracia e os dos grandes guerreiros. As responsabilidades de uma jali também incluíam a educação dos jovens príncipes; são os guardiões da tradição e da jurisprudência. Eles orientam os membros da aristocracia e cumprem as funções de conselheiros (...) Eles são conhecidos por sua verdade e exatidão sem distorção de fatos em seus 
relatos do passado. Isto certamente está entre os valores fundamentais que Camara Laye aponta como valores fundamentais sobre os quais ancora a civilização Mandinga, que incluem generosidade, lealdade, cavalheirismo, o respeito à palavra, a prática do Islã, a prática da kora e a noz-de-cola. Esta virtude está registrada na lenda de Sundjata relacionada a D.T. Niane por griot Mamadou Kouyate: 'Minha palavra é pura e livre de toda inverdade; é a palavra de meu pai; é a palavra do pai de meu pai'. Eu lhes darei as palavras de meu pai assim como as recebi; os griots reais não sabem o que é mentir. Quando surge uma disputa entre tribos, somos nós que resolvemos a diferença, pois somos os depositários dos juramentos que os ancestrais juraram (MUKUNA, 2020, grifos meus).

Marilena Chauí (1989) faz uma curiosa comparação entre ciência e religião que servirá como mais um interessante contraponto. De acordo com a característica essencial do positivismo científico - como concebido por Comte $^{11}$-, a devoção à ciência, vista como o único guia da vida individual e social, é a verdadeira moral e a única religião possível no asili yurugu. Esta premissa se tornaria um princípio e um valor do republicanismo das décadas e séculos seguintes - com seu lema expresso até mesmo na bandeira da República Federativa do Brasil, "Ordem e Progresso" (o que nos remete novamente aos domínios de Zeus). "É aqui que a expressão ‘a religião é o ópio do povo' atinge toda a sua verdade" (CHAUÍ, 1989, p. 78). Graças à magia secular da mídia impressa, uma nova crença poderia ser difundida: A razão passaria a ser inscrita nas próprias coisas (e, portanto, possível de ser acumulada, arquivada). A racionalidade torna-se o novo nome da "divina providência", e assim a ciência se torna o ópio do povo (CHAUÍ, 1989, p. 83) ${ }^{12}$.

\section{Arquivo morto, arquivo de morte: memória e o fetiche da acumulação arquivista}

Os acervos de museus etnológicos da Europa são a máxima demonstração do poder yurugu: o exercício do controle narrativo sobre si e seus empreendimentos coloniais sobre o restante do mundo. Esse exercício de poder passa, necessariamente, por apartar os

\footnotetext{
11 August Comte (1798-1857), considerado o primeiro filósofo no sentido moderno do termo e considerado o fundador da disciplina acadêmica Sociologia. Ele trabalhou na criação de uma filosofia positiva como uma tentativa de remediar o mal-estar social da Revolução Francesa, criando uma doutrina social baseada nas ciências que se tornariam uma "Religião da Humanidade".

${ }^{12}$ Hamilton Bernardes (CARDOSO, 1984) faz um comentário sobre a realidade brasileira específica a partir do postulado de Chauí, estendendo a passagem da magia à religião de massa e da providência divina à ciência em relação à questão racial: "É em nome da ciência e da democracia que o item 'cor' [raça] foi suprimido de todas as pesquisas, oficiais ou não, realizadas no país [Brasil - até aquela data]". Em nome da unidade nacional, quando feita por órgãos oficiais; da unidade histórica da classe trabalhadora, quando feita por órgãos de pesquisa sindical; da igualdade perante Deus, quando feita por órgãos religiosos, e, aqui, em nome da própria democracia racial, quando feita por órgãos independentes”. (...) a hipocrisia não é algo novo e a ciência é usada contra o povo em nome do progresso (...) é por isso que o Movimento Negro Unificado distribuiu um manifesto condenando a ciência como objeto de dominação (...) e convidando-os a apropriarem-se da ciência e a torná-la um instrumento de sua libertação. (...) para mostrar que a marginalidade dos brasileiros não-brancos não é um fenômeno puramente espiritual ou cultural, mas, sobretudo, uma marginalidade econômica que determina todo um universo de contradições econômicas, étnicas e nacionais. E não há duas maneiras de resolver as contradições econômicas: elas são resolvidas pela destruição da desigualdade. (...) Devemos olhar para a realidade em sua totalidade, dentro e fora de nosso gueto. Em outras palavras, é necessário libertar os homens e mulheres históricos que existem em cada negro e destruir os brancos históricos que existem nos homens. Ou seja, romper com a expansão das civilizações missionárias e abrir espaços para novos homens e mulheres” (CARDOSO, 1984, p. 56-57).
} 


\section{|Suelen Calonga |}

objetos de arte e cultura de seus contextos de sentido original e esvaziar a potência de comunicação holística desses objetos ao torná-los “objetos etnográficos”, especialmente se armazenados em uma instituição sob a justificativa retórica de "salvaguarda". Eu observo com interesse quando leio algum texto escrito por autor europeu (ou eurocêntrico) chamando as populações africanas de "fetichistas" por suas utilizações de objetos em práticas rituais ou cotidianas, quando, na verdade, percebo como o verdadeiro fetichismo a prática europeia de retirar esses objetos de seus contextos e sentidos de uso para compor as coleções de seus Arquivos nacionais. A etnografia é, a meu ver, o meio de expropriar e se apropriar dos "etno-saberes", quer seja pela coleta desses "objetos etnográficos", materiais ou imateriais, para análise e posterior arquivamento, sob o argumento da salvaguarda, quer seja pela prática de observação, descrição e registro academicista, de práticas e costumes dos "éthneos". O objetivo, sempre foi e sempre será, enriquecer e empoderar o detentor do Arquivo. A institucionalização das coleções dentro dos museus e arquivos - criadas com a vocação retórica de educação e preservação da memória - tem sempre um caráter político, "na medida em que a memória é um instrumento político, capaz de criar identidades, produzir um discurso sobre o passado e projetar perspectivas sobre o futuro" (HEYMANN, 2005).

Muitos autores ${ }^{13}$ falam sobre como os museus nacionais europeus organizaram suas coleções, principalmente a partir de roubos e pilhagens. Os primeiros viajantes aos países "distantes" foram comissionados por seus próprios governos para catalogar a diversidade cultural e biológica desses povos e lugares e trazer descrições detalhadas e amostras de tudo o que pudessem encontrar: de plantas a animais, de imagens a pessoas. Este aspecto da colonialidade é, ao mesmo tempo, forma e conteúdo de uma "matriz de poder que produz hierarquias raciais e de gênero em nível global e local, operando junto com o capital para manter um regime moderno de exploração e dominação" (QUIJANO, 1997; QUIJANO, 1992). E mesmo quando os museus tentam se "defender" dos apontamentos de que seus acervos são frutos de massacres, roubos e pilhagens, sob o argumento que "nem tudo foi

\footnotetext{
13 Entre os europeus posso destacar Barbara Kirshenblatt-Gimblett, que faz contribuições interdisciplinares importantes à teoria e história dos museus, turismo e patrimônio; Dan Hicks, que explicita como o violentíssimo ataque naval britânico contra a Corte Real da Cidade de Benin, Nigéria, em 1897, gerou um dos maiores tesouros patrimoniais europeus, a coleção conhecida como Benin Bronzes, composta de milhares de placas de latão e presas de marfim esculpidas retratando a história do local de origem e roubadas como represália à tentativa de resistência ao empreendimento colonial britânico; e Bénédicte Savoy, historiadora da arte especialista em "deslocamento" de obras de arte (incluindo roubo de arte e arte saqueada). Entre os nãoeuropeus, indico Felwine Sarr, cientista social senegalês que conduziu, junto com Savoy, o imenso Relatório de Restituição de Patrimônio Cultural Africano, onde está catalogada em mais de 7 mil páginas todos os artefatos de origem africana atualmente em poder dos museus nacionais franceses; e Monica Hanna, egiptóloga egípcia e uma das maiores referências na luta contra o comércio ilícito de antiguidades.
} 


\title{
|Suelen Calonga |
}

roubado, parte foi doada ou comprada"14, a narrativa tenta esconder, ou apagar, a informação que foram doados ou comprados de coleções particulares frutos de massacres, roubos e pilhagens.

Barbara Kirshenblatt-Gimblett explora o paradoxo de exibir objetos etnográficos em museus ${ }^{15}$, já que, uma vez obtidos, nunca mais deixarão de ser apenas fragmentos

\begin{abstract}
criados por etnógrafos quando os definem, segmentam, destacam e os transportam. Tais fragmentos tornam-se objetos etnográficos em virtude da maneira como foram destacados. São o que são em virtude das disciplinas que os 'conhecem', pois as disciplinas fazem seus objetos e, no processo, se fazem a si mesmas. (...) Eu quero sugerir que objetos etnográficos são feitos, não encontrados (...) eles não começaram suas vidas como objetos etnográficos. Eles se tornaram etnográficos através de um processo de desprendimento e contextualização. Se nesse processo os objetos deixam de ser o que já foram, é uma questão aberta e importante. Essa questão fala da relação de origem e destino, da economia política de exibição. A resposta testa a alienabilidade do que é coletado e mostrado (KIRSHENBLATT-GIMBLETT, 1998, p. 2-3).
\end{abstract}

Isso significa, portanto, que o processo de tentar construir uma memória sobre o lugar de origem dos objetos a partir da etnografia; a tentativa de atribuir a esses objetos a possibilidade de arquivarem a memória, inscrevendo neles forçadamente, uma narrativa que não emana deles próprios ou se seus usuários/detentores originais e, pior, não registrando nessa narrativa as formas pelas quais os objetos foram adquiridos, torna esses Arquivos europeus, verdadeiros Arquivos mortos, ao mesmo tempo que Arquivos de morte: um acumulado de objetos sem sentido que, da forma como são armazenados e exibidos, não narram sequer a memória da morte física e epistemológica dos próprios objetos e das pessoas que faziam uso deles anteriormente.

Não por um acaso, o asili europeu é denominado por eles mesmos como cosmovisão: a memória seria apreendida através do olho, e os objetos pelos quais a memória poderia ser acessada seriam, principalmente, objetos visuais. Leda Martins (2003) afirma que este uso repetido do significante memória, orquestrada desse lugar privilegiado de reconhecimento, a escrita física, torna difícil "pensar a memória em seus outros ambientes, nos quais ela também está inscrita, escrita e postulada: a vOz e o corpo, desenhados nos campos das performances de oralidade e práticas rituais" (MARTINS, 2003, p. 63), nos quais está inscrita a maior parte dos repertórios narrativos e poéticos de experiências nãoeuropeias. Quase sempre, essas "performances de oralidade" acontecem junto a (ou

\footnotetext{
14 Veja matéria da Revista Super Interessante: < $\underline{\text { https://super.abril.com.br/historia/na-mao-leve-roubos- }}$ historicos $/>$.

$15 \mathrm{O}$ autor também cita neste texto um aspecto importante que seria a prova definitiva da eficácia no papel dos museus europeus como empreendimentos educacionais sobre sua própria visão de mundo (europeia): as "performances patrimoniais", as formas teatrais que os países colonizados têm de imitar e transmitir mensagens de modernidade, emulando o que seria a "aparência europeia".
} 


\title{
|Suelen Calonga |
}

dependente de) objetos, ritualísticos ou cotidianos, manipulados pelos detentores das tecnologias holísticas e dos saberes civilizatórios não-brancos, e, na impossibilidade de apreender em objetos concretos as próprias performances e práticas rituais, apreende-se os próprios objetos usados, ou confina-os em descrições escritas sobre o exotismo dessas práticas, alvos da ganância yurugu para alimentar seus arquivos ${ }^{16}$.

\begin{abstract}
Neste sentido, o domínio da escrita torna-se uma metáfora para uma ideia quase exclusiva da natureza do conhecimento, centrada na primazia da visão, que imprime no campo óptico sua percepção. A memória (...) articula-se no campo e no processo de visão mapeado pelo olho, apreendido como a janela do conhecimento. Tudo que escapa, portanto, à apreensão do olhar (...) é exótico [ex-óptico], fora de nosso campo de percepção, distante de nosso ponto de vista de compreensão, exilado e alienado de nossa contemplação, de nosso conhecimento (MARTINS, 2003, p. 64).
\end{abstract}

A acumulação ou compilação sistemática destes objetos de memória (arquivamento) traz a ideia de legado patrimonial, ou acervo: uma ligação temporal entre o que necessariamente se refere ao passado, mas é projetado para o futuro. Portanto, uma coleção de objetos elevada à categoria de legado (de uma nação, por exemplo), cria uma atualização permanente do significado de sua criação, pois promove o vínculo entre, por um lado, memória e história e, por outro, o poder e o controle sobre a narrativa baseado na prova objetiva adquirida da propriedade dos objetos. A coleção destes objetos de memória tornase, tanto mais importante quanto mais "registros de fatos históricos" acumulam.

Qualquer coleção retrata melhor o colecionador do que a história dos objetos transformados em coleção. No caso dos bens etnográficos, quando observamos todos eles reunidos em um mesmo lugar, vemos uma imagem muito clara da pessoa ou da sociedade que os reuniu e os transformou em uma coleção. Enquanto o asili yurugu se estabelece como modelo e centro de produção do conhecimento sobre o mundo, ele apresenta no colecionismo a mais profunda expressão da estrutura de seu pensamento cultural. $\mathrm{O}$ fetichismo sobre estes objetos de memória é um dos pilares mais fortes que sustentam o universo simbólico do espírito colonizador europeu, e tem servido como justificativa para a contínua expropriação material e cultural de outros povos e o arquivamento desse espólio em acervos institucionalizados de museus nacionais europeus. Não importa o quanto a propriedade das peças que formam uma coleção muda de mãos, as instituições mudem de nome ou a sociedade passe por transformações que alteram o significado de uma coleção

\footnotetext{
16 O que se torna um duplo movimento, paradoxal: de um lado, ao apartar o objeto que apoia a prática cultural de seu detentor sob a justificativa de salvaguarda, se dificulta intencionalmente o acesso e a perpetuação daquela mesma prática e, por outro, se reforça o discurso de que apenas o arquivamento é capaz de salvaguardar aquela prática de sua extinção.
} 
ao longo do tempo, o caráter da intencionalidade de sua formação segue o núcleo da coleção enquanto ela existir.

\section{Genocídio é o braço colonial mais forte, Epistemicídio é o seu braço mais longo}

Apesar dos conceitos de arquivo, memória, legado e história discutidos acima serem de grande importância para a compreensão da dimensão geral do assunto aqui discutido, não posso deixar de destacar a dimensão prática e concreta dos papéis desempenhados pelos Arquivos nacionais europeus na política global, especialmente entre o séc. XVIII (quando a maioria delas foi estabelecida) e o séc. XX (quando começaram a ser questionadas como instrumento de políticas estatais). É aqui que reside o verdadeiro exercício do poder destas instituições, dado que trabalham, ainda hoje, em apoio a seus governos na interdição da soberania de outros povos e territórios, e no apagamento seletivo da magnitude global de fatos históricos.

Dois eventos que ocorreram neste período reestruturariam completamente as relações internacionais entre nações do mundo inteiro e estão intimamente ligados à questão da criação e consolidação dos Arquivos europeus: a Revolução Haitiana (de agosto de 1791 a janeiro de 1804) e a Conferência de Berlim (de novembro de 1884 a fevereiro de 1885).

A Revolução Haitiana teve um impacto tão grande na estrutura colonialista que as expressões haitianismo ou ameaça haitiana começaram a aparecer em muitas cartas e documentos oficiais em todo o mundo, especialmente nas Américas e no Caribe (TORRES-SAILLANT, 2012), principalmente porque menções à revolução foram censuradas em muitas partes da Europa, em especial na França. O haitianismo transmitia a ideia de que a hegemonia colonialista europeia não estava tão cristalizada quanto as estruturas de poder gostariam de acreditar, uma vez que o Haiti - anteriormente chamado de Saint-Domingue, economicamente a colônia mais importante do império francês conseguiu se organizar, derrubar o regime colonialista e expulsar da ilha (ou matar) todos os yurugu. Os supremacistas ${ }^{17}$ perceberam que se os haitianos - imbuídos do espírito revolucionário e estratégias de guerrilha impecáveis - conseguiram derrubar as poderosas armadas do grande Napoleão Bonaparte, ainda que escravizados, fundando a primeira República Negra, e a primeira abolição completa da escravidão nas Américas, não

\footnotetext{
17 “Cientistas, pensadores, intelectuais, ideólogos e políticos que investem seus recursos principalmente ou parcialmente na elaboração de justificativas para o racismo ou para o colonialismo, ou que investem na elaboração de estratégias para manter ou fortalecer a estrutura racista - como os autores do chamado "racismo científico" do passado e do presente, líderes extremistas, neoliberais e qualquer pessoa de qualquer área que crie ou tenha criado qualquer forma de apoio direto ou atenção indireta ao pensamento racista ou ao projeto colonialista (FREIRE, 2020)".
} 


\section{|Suelen Calonga |}

demoraria muito para que todos os impérios escravocratas começassem a desmoronar. Era necessário e urgente, portanto, uma interdição coordenada na filosofia política europeia: a manipulação do discurso oficial europeu ao qual Susan Buck-Morss, em "Hegel e o Haiti" (2017) já tão brilhantemente descreveu e analisou, que faço desnecessária minha adição aqui, encaminhando o leitor diretamente à leitura de sua obra.

Neste ponto, o colonialismo começa a calcular que se utilizar "somente da violência física é o método menos eficaz para perpetuar estruturas de opressão e exploração" (FREIRE, 2020). Por outro lado, "a violência física, combinada com a dominação cultural, ideológica, política e econômica, inclina-se para a indestrutibilidade da estrutura imperialista que serve" (ibid.). Se o total genocídio dos povos colonizados não seria lucrativo (ou possível), era preciso criar algo mais sutil, porém de longo e perpétuo alcance. O colonialismo começa, a partir dessa percepção, a sofisticar continuamente seus mecanismos de exploração com especial atenção no controle narrativo, com expressiva participação dos Arquivos nacionais europeus, exportando o modelo educacional do museu francês para outros países, inclusive, o Brasil $^{18}$.

O outro exemplo de controle narrativo é a Conferência de Berlim, que articulada pelas grandes potências coloniais europeias para evitar guerras entre si nos processos de divisão, ocupação e exploração do continente africano, decidiu implementar conjuntamente a narrativa de que os europeus tinham por dever moral "civilizar" a África. Uma narrativa que, para a opinião pública, justificaria as atrocidades mais horríveis já realizadas no mundo, com inúmeros genocídios, torturas maciças e sistemas de trabalho desumanizante durante todo o século 20 até os dias de hoje (o processo colonizatório não terminou com a recente desocupação dos territórios). Esta fraude foi meticulosamente fabricada por inúmeros intelectuais e formadores de opinião, dos quais a narrativa do "Fardo do Homem Branco" de Kipling (1899) ${ }^{19}$ tornou-se particularmente famosa e especialmente representativa dos níveis ilimitados de aparelhamento da arte para consolidação do cinismo e racismo yurugu, procedimento que, nas décadas seguintes, contaminou o mundo todo.

\footnotetext{
${ }^{18}$ Cecília Rodrigues dos Santos (2018) demonstra muito claramente a concepção de patrimônio importada da França por Mário de Andrade e expressa na sua relação com as ideias de etnografia e folclore em debate nos anos 1930, a partir da elaboração do "Anteprojeto para a criação do Serviço do Patrimônio Histórico e Artístico Nacional", que deu origem ao atual IPHAN.

19 Rudyard Kiplin foi um poeta do imperialismo inglês (nascido na Índia), e escreveu esse poema em celebração do jubileu de diamante da Rainha Vitória. Nele, Kipling representa positivamente o imperialismo colonial como o fardo moral da raça branca, que está divinamente destinada a civilizar os povos brutos e nãobrancos que habitam as partes bárbaras do mundo. Kipling proferiu pessoalmente seu poema para o então governador de Nova York, Theodor Roosevelt (1899-1900) para ajudá-lo a persuadir os americanos antiimperialistas a aceitar a anexação territorial das Filipinas aos Estados Unidos. < $\underline{\text { https://en.wikipedia.org/wiki/The White Man\%27s Burden>. }}$
} 
Como nas palavras do cientista político queniano Ali Mazrui (1986), o casamento entre a "curiosidade científica e o apetite econômico" da Europa organizou discursivamente todos os setores e todos os estratos das sociedades europeias em uma agenda unificada: construir um império global através da expropriação total dos recursos naturais e culturais de todos os povos não-europeus do mundo. Em uma guerra total, com frentes violentamente coercitivas, e fortíssimas frentes conceituais, ideológicas, culturais e políticas, colocadas em lugares estratégicos - dos quais a etnologia é o exemplo que trago, e não coincidentemente o que escolhi para lutar contra. Em resumo, o adágio socrático "conhece-te a ti mesmo" havia se tornado uma grande falácia, e "conhecer-se através da alteridade" o cúmulo do cinismo: na verdade, o que a Europa queria era açúcar e diamantes.

\section{O DUPLO MOVIMENTO: autodeterminação e contra-etnografia}

- Como vocês podem nos ensinar a sobreviver em nosso próprio mundo? Como vocês podem saber o suficiente sobre ele, ou sobre nós?

- Como não saberíamos? Ajudamos seu mundo a se recuperar. Estudamos seus corpos, seu pensamento, sua literatura, seus registros históricos, suas muitas culturas... Sabemos mais sobre o que vocês são capazes do que vocês mesmos.

Octavia E. Butler, Despertar, 2018, p. 32.

Ao longo do século XX, especialmente desde as guerras dos países africanos pela independência dos europeus, e nas lutas dos países latino-americanos pela soberania diante do domínio norte-americano, muitos filósofos, historiadores, cientistas sociais, artistas, cineastas e autores de diferentes áreas têm proposto discussões transnacionais mais amplas sobre os danos que as práticas epistemicidas do asili europeu causam às nossas subjetividades. Reflexões sobre a noção de representação e as relações entre diferentes sistemas de representação (HALL, 1992), o papel das narrativas na constituição de indivíduos e grupos sociais (SANTOS \& MENESES, 2010), os efeitos da adoção de um único paradigma globalizador (SILVA, D. F., 2007), as políticas de silenciamento (KILOMBA, 2010), o epistemicídio (CARNEIRO, 2005), as hierarquizações impostas pelo asili branco nas teorias sociais e nas relações étnico-raciais (MUNANGA, 2009), as formas de colonização territorial e, sobretudo, a colonização psicológica como estruturadoras da modernidade (FANON, 1961), só para citar mais alguns autores expoentes no momento, são temas abordados em torno do domínio branco-europeu e do primado epistemológico da ciência moderna a partir do século XVII. Da minha parte, aqui, proponho a contraetnografia como um caminho de retomada para a nossa autodeterminação. 


\title{
Reconhecer que fomos enganados e roubados
}

O primeiro passo para restaurar a nossa soberania é sairmos da condição de povos colonizados; é reconhecer que a colonização há muito deixou de ser territorial e está instalada em nossa mente coletiva; é reconhecer que entramos em uma guerra que não desejamos e que, uma vez dentro dela, ainda não fizemos todos os movimentos necessários para sairmos vitoriosos. Às vezes por nos faltar força para resistirmos, às vezes por faltar a percepção de que estamos sendo subtraídos e devemos reagir. Necessitamos compreender que a "História é uma arma" yurugu, que temos sido sistematicamente e intencionalmente "deseducados" (WOODSON, 1933) de tudo o que garantiria nossa liberdade e emancipação nas escolas brancas, e que nossa história é muito anterior e muito mais gloriosa. Se a (in)civilização yurugu cair hoje, ela não terá durado metade do que qualquer outra que existiu antes. O asili europeu se impôs de tal forma sobre nossas mentes que passamos a acreditar que não somos capazes de ter propriedade sobre nossas próprias invenções, fazer a manutenção das nossas próprias práticas ou guardar da melhor forma os objetos que nós mesmos criamos, para nosso próprio uso. Fomos roubados e não podemos mais ser, ao mesmo tempo, cúmplices e vítimas dos ladrões.

\begin{abstract}
Quando testemunhamos uma pessoa agredindo outra, por exemplo, pegando o casaco da outra à força, não elogiamos o assaltante, não elogiamos seu novo traje e não o parabenizamos por possuir um casaco tão bonito, quente, elegante, confortável e adquirido de uma maneira tão inteligente. Abominamos o que ele fez e, idealmente, nos esforçamos para devolver à vítima o que lhe foi roubado. Entretanto, quando a mesma situação ocorre exatamente diluída durante milhares de anos e espalhada por todas as regiões do mundo, temos dificuldade de identificar o ladrão e acabamos absolvendo-o de seu crime. Obviamente, no segundo caso, o fato de o assaltante ter o controle da mídia sobre a sociedade facilita sua impunidade. Entretanto, independentemente dos mecanismos de controle narrativo, uma vez identificados o roubo e o assaltante, temos a obrigação de nos engajar na reparação do roubo, punindo o assaltante e restaurando a propriedade usurpada, sob pena de nos considerarmos imorais e de sermos condenados como cúmplices do crime em questão (FREIRE, 2020).
\end{abstract}

\section{Conhecer o inimigo e subverter a estratégia de guerra}

Em uma guerra, é necessário que se conheça bem o inimigo para combatê-lo, ainda - e principalmente - se o objetivo final da guerra é o estabelecimento da paz. Sugiro uma atenção especial ao fato de que o asili europeu é centrado na total ausência de noção sobre quem eles são de verdade. A Etnologia, como defendo ser a matéria que compõe esse asili não os ajuda a entenderem melhor quem são, mas apenas quem eles não-são. Nós temos condição de entendê-los melhor do que eles mesmos. Mas não podemos olhá-los como referência - precisamos buscar nossos próprios referenciais desde antes da colonização. 


\section{|Suelen Calonga |}

Um exemplo de simples entendimento é que nossa espiritualidade costumava ser baseada em deuses criados a partir de nossa semelhança, e hoje as imagens (visuais e conceituais) de Deus não se assemelham em nada a nós mesmos, e temos dificuldade até de perceber isso dada a intensidade e profundidade de nossos defeitos de autoimagem e rupturas cognitivas que nos fazem buscar referenciais em quem quer nos destruir. Estamos na posição privilegiada de entender quem eles são a partir do que eles não-são: nós.

Minha sugestão é que, uma vez que sejamos capazes de entender e reconhecer os processos aos quais fomos submetidos (e apenas após esse entendimento), que façamos o movimento de contra-etnografar o inimigo, aproveitando a abundância de subsídios que nos informam quem são eles e como agem, para entender em profundidade os processos e procedimentos com os quais eles nos controlam. E nos defender.

A contra-etnografia como o movimento de identificação, entendimento e subversão dos processos e procedimentos etnográficos que, adicionados a autodeterminação, nos permite reivindicar e estabelecer novos limites entre nós e eles, ou melhor: entre o que nós verdadeiramente somos e o que eles nos fizeram acreditar que somos a partir da leitura intencionalmente equivocada de nós. A contra-etnografia seria, portanto, minha proposta de caminho possível para restabelecer nosso controle sobre nossas próprias narrativas, restabelecer nosso poder. Isso demanda em parte tomar de volta o que foi roubado, mas também abandonar certas coisas que foram usurpadas e controladas em um nível tão profundo que seria melhor rompermos com o modelo do que tentar reformá-lo, por exemplo, entendimentos ocidentais muito sedimentados, como conceitos "arte" e "religião", que não estão desenvolvidos aqui.

\section{Kujichagulia e a restauração do poder sobre nossas próprias vidas}

Compreender as relações de poder que atuam mutuamente para gerar o processo de construção (ou destruição) de uma memória (ou de um esquecimento) é compreender as negociações feitas para se alcançar o poder de controlar uma narrativa. E no ponto que estamos, muito perto de uma total perda de controle sobre nossas próprias narrativas, se faz urgente uma (re)organização estruturada com vistas a restabelecer nossa autodeterminação, kujichagulia ${ }^{20}$, em nível individual e, sobretudo, coletivo.

\footnotetext{
20 Maulana Karenga, em 1966, partindo dos ideais expressos no Nacionalismo Preto e no Pan-africanismo, como propagados por Malcolm X, de que as populações pretas das Américas deveriam voltar à África, se não fisicamente, pelo menos culturalmente e espiritualmente, criou o feriado Kwanzaa, como alternativa às comemorações de final de ano para as populações pretas diaspóricas. Esse feriado é uma celebração ritual com duração de 7 dias, entre o dia 26 de dezembro e 1 de janeiro, na qual cada dia corresponde a um dos "sete princípios da herança africana". Kujichagulia, uma palavra no idioma Kiswahili que significa “autodeterminação", é celebrada no segundo dia, como forma de nos lembrar constantemente de que é preciso que retomemos a capacidade de definir-nos, nomear-nos, criar por nós mesmos e falar por nós
} 


\section{|Suelen Calonga |}

Exu, o dono dos caminhos, senhor de todas as possibilidades e mantenedor da ordem e da desordem do universo nos ensina que apenas ele é capaz de fazer o acerto virar erro e o erro virar acerto. Pegaremos, pois, o erro que nos foi imposto e, armados do princípio de kujichagulia, faremos dele o nosso acerto. "Desatar os nós para lançar novas amarrações" (RUFINO, 2016), sem que caiamos de novo e de novo nas narrativas falaciosas yurugu. A chave "decolonial” já foi cooptada, eles já se dizem hoje "antirracistas" e até mesmo a "autodeterminação" consta como direito humano "universal” (!) na carta da ONU, organização yurugu que interfere na soberania de países sempre que ousam contrariar o asili europeu, haja vista a ocupação do Haiti.

É preciso estar muito atento. Eles tentarão o tempo todo nos fazer acreditar que eles estão mudando a nosso favor e que o melhor para todos é que nós nos juntemos a eles. Na mesa deles. Mas o que precisamos é falar e estar mais uns com os outros, restaurarmos nossos idiomas originais, nossos nomes originais, nossa espiritualidade original. A nossa percepção holística de nós mesmos e do mundo ao nosso redor, de forma incompreensível a eles, e totalmente compreensível e verdadeira a nós. Retraçar os limites entre nós e eles de forma que esses limites sejam traçados por nós e sirvam a nós, para que consigamos distinguir com clareza o que somos e o que eles nos fizeram acreditar que somos. Dispensar o segundo e exaltar o primeiro, com a clareza e tranquilidade de saber que quando nos levantarmos, o rebote será violento. Que saibamos, mais do que resistir, reagir.

\section{(IN)CONCLUSÕES}

Quando você controla o pensamento de um homem, você não precisa se preocupar com suas ações. Você não tem que dizer a ele para não ficar aqui ou ir para lá. Ele encontrará seu 'lugar adequado’ e permanecerá nele. Você não precisa mandá-lo para a porta dos fundos. Ele irá sem ser avisado. Na verdade, se não houver porta dos fundos, ele fará uma para seu próprio uso.

Carter G. Woodson. A Deseducação do Negro, 1933.

Voltaremos agora à encruzilhada "o que é poder?" para nos perceber atravessados por muitos e diferentes papéis impostos, conflituosos entre nossos posicionamentos éticos, estéticos, espirituais e políticos originais. Exu, o princípio cosmológico iorubano, ao mesmo tempo símbolo e signo, responde pra mim que ele é o verdadeiro poder, e é dele a

mesmos. Um vídeo onde o próprio Karenga explica as razões do Kwanzaa pode ser visto em: $<\underline{\text { https://youtu.be/c-MY8I kwJY> }}$. 
face do Deus que nos reflete, é pra ele que devemos olhar se desejamos saber quem verdadeiramente somos. Ele é o princípio cosmológico onde estão

\begin{abstract}
assentadas as noções acerca das estruturas, composições e dinâmicas do universo. (...) Exu está também vinculado a uma problemática epistemológica. $\mathrm{A}(\mathrm{s})$ sua(s) presença(s) cruza(m) esse debate, já que as questões acerca dos conhecimentos estão diretamente ligadas a seus princípios e potências. Nesse sentido, está vinculado às produções, presenças e origens dos conhecimentos. Ainda sob essa dimensão, o orixá protagoniza suas peripécias no que tange as questões relativas à diversidade de conhecimentos e a necessidade de giros, transgressões e rebeldias frente aos processos de colonização/racismo epistemológico (RUFINO, 2016, p. 2).
\end{abstract}

Existe um conhecimento Africano transmitido por tradição oral que informa que a consciência não tem poder sobre si mesma, ela é uma potência de ação fecundada pelo corpo. Que seria apenas o estado de transe que acontece no subconsciente (Auset, na tradição do antigo Kemet) que possui o poder necessário para controlar as ações do mundo físico. O subconsciente seria o local onde ficam arquivadas nossas informações culturais. $\mathrm{E}$ por isso Geb (o mundo físico/corpo) deve copular com Nwt (o subconsciente/espírito) para que haja a criação. Isso quer dizer que apenas a manipulação em nível sutil das coisas que são arquivadas no subconsciente individual e coletivo poderia alterar a forma com a qual o poder se expressa no mundo. Sabendo disso, o colonialismo controla nossos corpos para que não sejam fecundados pela nossa mente. Somos, cada um de nós, o nosso próprio arquivo, porque o nosso subconsciente é coletivo e muito, muito antigo. E nele está guardado tudo aqui que achamos que nos falta hoje, mas que nos sobra. "Enquanto o colonialismo edificou a cruz como sua égide, sobrevivemos vadiando nos vazios deixados, ocupando e inventando as esquinas da modernidade ocidental, praticando as encruzilhadas como um campo de possibilidades" (RUFINO, 2016, p. 2). Temos e somos muito, porque tivemos e fomos muito, e por isso teremos e seremos muito. Que saibamos não ser bons com quem é ruim com a gente, oferecer a outra face não é coisa nossa. Que saibamos usar nosso centro de inteligência ancestral (o coração, não a cabeça) para parecermos ininteligíveis.

A contra-etnografia, um primeiro passo que dei em direção a uma brincadeira séria que proponho, é um caminho de "desobediência epistêmica" (MIGNOLO, 2008) e "traquinagem exusíaca", um "pequeno golpe, uma mandinga, uma anti-disciplina" (RUFINO, 2016) que nos fará, assim como Exu, matar hoje o pássaro com a pedra atirada ontem. Ela vai parecer, num primeiro momento, que a assimilação de uma prática yurugu e uma tentativa de "mudar o sistema por dentro", e é bom que pareça assim, apesar de estar muito longe de ser. A essa altura já sabemos que muitas coisas que parecem ser, não são. A 
rua ensina que malandro é malandro e mané é mané. Quem me entendeu eu agradeço, e quem não me entendeu, procure me entender.

\section{REFERÊNCIAS}

ANI, Marimba (RICHARDS, Dona). Yurugu: An African-centered Critique of European Cultural Thought and Behavior. Trenton: Africa World Press, 1994.

BENTO, Maria Aparecida Silva. Pactos narcísicos no racismo: branquitude e poder nas organizações empresariais e no poder público. São Paulo: Universidade de São Paulo, 2002.

BUCK-MORSS, Susan Buck-Morss. Hegel e o Haiti. São Paulo: n-1edições, 2017.

CALONGA, Suelen. Why do the Archives archive? A journey from the hunko to the counter-ethnography and back. 2020. Dissertação (Mestrado em Arte Pública e Novas Estratégias Artísticas) - Bauhaus-Universität, Weimar, 2020.

CARDOSO, Hamilton Bernardes. Movimentos negros: é preciso, ou Aspectos econômicos da opressão racial. Afrodiáspora - Revista do mundo negro, São Paulo: IPEAFRO, ano 2, n. 3, p. 43-57, jan. 1984. Disponível em: $<$ https://issuu.com/institutopesquisaestudosafrobrasile/docs/afrodi spora volume $3>$.

Acesso em: 20 jul. 2020.

CARNEIRO, Aparecida Sueli. A construção do outro como não-ser como fundamento do ser. São Paulo: Universidade de São Paulo, 2005.

CHAGAS, Mário de Souza. Memória e poder: dois movimentos. Estudos Avançados de Museologia. Lisboa: Universidade Lusófona de Humanidades e Tecnologias, 2011.

CHAUÍ, Marilena. Cultura e Democracia: o discurso competente e outras falas. São Paulo: Cortez Editora, 1989.

FANON, Frant. The Wretched of the Earth. London: Penguin Books, 2001 [1961].

FLUSSER, Vilém. Filosofia da Caixa Preta: ensaios para uma futura filosofia da fotografia. São Paulo: Editora Hucitec, 1985.

FREIRE, Kamai. Intangible Cultural Heritage and Transatlantic Connections: Panafricanism and African Revolution in Brazilian Music. 2020. Dissertação (Mestrado) Instituto de Musicologia da Hochschule für Musik Franz Liszt Weimar/Friedrich-Schiller Universität Jena, Weimar, 2020.

GONÇALVES, Mariana Couto. O diálogo entre Clio e Calíope: os enlaces entre dois gêneros distintos. Revista Latino-Americana de História, v. 3, n. 12, dez. 2014. Disponível em: <https://dialnet.unirioja.es/servlet/articulo?codigo=6238522>. Acesso em: 20 jul. 2020.

GRAEFF, Nina. Notas negras, pautas brancas: abertura do dossiê Matizes Africanos na Música Brasileira. Revista Claves, v. 13, n. 15, 2020. 
HALL, Stuart. The Question of Cultural Identity. In: HALL, Stuart; HELD, David; MCGREW, Anthony (Org.). Modernity and its Futures. Cambridge: Polity Press, 1992, p. 274-316. Disponível em: $<$ https://www.academia.edu/4362995/Hall S Questions Of Cultural Identity $>$. Acesso em: 20 jul. 2020.

HAMPATÉ BÂ, Amadou. The Living Tradition in General History of Africa. In: KIZERBO, Joseph (Org.). Methodology and African Prehistory. Los Angeles: University of California Press, 1981. Disponível em: < https://unesdoc.unesco.org/ark:/48223/pf0000042225>. Acesso em: 20 jul. 2020.

HEYMANN, Luciana. De arquivo pessoal' a 'patrimônio nacional': reflexões acerca da produção de 'legados'. Rio de Janeiro: CPDOC, 2005. Disponível em: < https://www.researchgate.net/publication/348429806 Why do the Archives ar>. Acesso em: 20 jul. 2020.

KILOMBA, Grada. Plantation Memories: Episodes of Everyday Racism. Münster: Unrast, 2010

KIRSHENBLATT-GIMBLETT, Barbara. Destination culture: tourism, museums, and heritage. Los Angeles: University of California Press, 1998.

MANDAVILLI, Sujay Rao. Presenting the "Structures and Annotated Participant-driven Appraisal" technique in ethnography: Towards the universal realization of multivocality in ethnographic studies. ELK's International Journal of Social Science, v. 4, n. 4, 2018.

MARTINS, Leda Maria. Performances da Oralitura: corpo, lugar de memória. Letras, n. 26, p. 63-81, 2003. Disponível em: <https://periodicos.ufsm.br/letras/article/view/11881>. Acesso em: 20 jul. 2020.

MASSIMI, M. Imaginação e imagens: conceitos e práticas em tradições culturais da modernidade ocidental e do Brasil colonial. Memorandum, v. 23, p. 158-184, 2012. Disponível em: < http://www.fafich.ufmg.br/memorandum/a23/massimi06 >. Acesso em: 20 jul. 2020.

MAZRUI, Ali. A Legacy of Lifestyles (episode 2). The Africans: A Triple Heritage (tv series). Washington, London, Abuja: BBC TV, PBS, NTA, 1986.

MENEZES BASTOS, Rafael J. Esboço de uma teoria da Música: para além de uma Antropologia sem Música e de uma Musicologia sem Homem. Anuário Antropológico, Rio de Janeiro: Tempo Brasileiro, p. 9-73, 1995.

MIGNOLO, W. D. Desobediência epistêmica: a opção descolonial e o significado deidentidade em política. Cadernos de Letras da UFF - Dossiê: Literatura, língua e identidade, n. 34, p. 287-324, 2008. Disponível em: $<$ http://professor.ufop.br/sites/default/files/tatiana/files/desobediencia epistemica mig nolo.pdf>. Acesso em: 20 jul. 2020.

MUKUNA, Kazadi wa. Chordophones of Africa. Online Course - Music in Africa. UNESCO Chair on Transcultural Music Studies. Weimar: HfM Franz Liszt Weimar-Jena, 2020. 
MUNANGA, Kabengele. Introdução à teoria social e relações sociais - Educação para relações étnico-raciais. [Online]. Niterói: Universidade Federal Fluminense - UFF, 2009. Disponível em: < https://youtu.be/7FxJOLf6HCA>. Acesso em: 20 jul. 2020.

BUTLER, Octavia E. Despertar. Xenogênese. São Paulo: Morro Branco, 2018. v. 01.

PESAVENTO, Sandra Jatahy. História \& História Cultural. Belo Horizonte: Autêntica, 2003.

QUIJANO, Aníbal. Colonialidad del poder, cultura y conocimiento en América Latina. Anuario Mariateguiano, v. 9, n. 9, 1997.

QUIJANO, Aníbal. Colonialidad y modernidad-racionalidad. Perú Indígena, v. 13, n. 29, 1992.

ROUILLÉ, André. A fotografia entre documento e arte contemporânea. São Paulo: Senac, 2009.

RUfINO, Luiz. Exu e a Pedagogia das Encruzilhas. Conferência proferida no Seminário dos Alunos PPGAS-MN/UFRJ. Rio de Janeiro, 2016. Disponível em: < https://www.academia.edu/32012934/EXU E A PEDAGOGIA DAS ENCRUZIL HADAS Luiz Rufino PPGAS MN UFRJ>. Acesso em: 20 jul. 2020.

RUFINO, Luiz. Pedagogia das Encruzilhadas. Revista Periferia, v. 10, n. 1, p. 71-88, jan./jun. 2018. Disponível em: publicacoes.uerj.br/index.php/periferia/article/view/31504/>. Acesso em: 20 jul. 2020.

SANTAELLA, Lúcia; NÖTH, Winfried. Imagem: cognição, semiótica, mídia. São Paulo: Iluminuras, 1998.

SANTOS, Boaventura; MENESES, Paula. Epistemologias do Sul. São Paulo: Cortez, 2010.

SANTOS, C. R. dos. O patrimônio de Mário de Andrade: tirando o pedregulho da botina para não manquejar. Revista CPC, v. 13, n. 25, ed. esp., p. 11-47, 2018. Disponível em: <https://www.revistas.usp.br/cpc/article/view/144681>. Acesso em: 20 jul. 2020.

SILVA, Denise Ferreira da. Toward a Global Idea of Race. Minneapolis, London: University of Minesota Press, 2007.

SUANO, Marlene. O que é museu? São Paulo: Ed. Brasiliense, 1986.

TORRES-SAILLANT, Silvio. El anti-haitianismo como ideología occidental. Cuadernos Inter.c.a.mbio, v. 9, n. 10, p. 15-48, 2012.

TZU, Sun. A arte da guerra. Tradução de Sueli Barros Cassal. Porto Alegre: L\&PM, 2006.

VELTHEM, Lucia Hussak van. O objeto etnográfico é irredutível? Pistas sobre novos sentidos e análises. Boletim do Museu Paraense Emílio Goeldi. Ciências Humanas, v. 7, n. 1 , p. 51-66, jan./abr. 2012. Disponível em: $<$ https://edisciplinas.usp.br/pluginfile.php/3753417/mod resource/content $/ 1 / \operatorname{van} \% 20 \mathrm{~V}$ elthem.pdf>. Acesso em: 20 jul. 2020. 
WOODSON, Carter G. The miseducation of the negro. Washington: The Associated Publishers, 1933. Disponível em: < http://historyisaweapon.com/defcon1/misedne.html>. Acesso em: 20 jul. 2020.

\section{Como citar este artigo:}

\section{ABNT}

CALONGA, S. Em direção à contra-etnografia. InterEspaço: Revista de Geografia e Interdisciplinaridade, v. 6, e202032, 2020. Disponível em: <http://dx.doi.org/10.18764/2446-6549.e202032>. Acesso em: 27 dez. 2020.

\section{APA:}

Calonga, S.. (2020). Em direção à contra-etnografia. InterEspaço: Revista de Geografia e Interdisciplinaridade, v. 6, e202032. Recuperado em 27 dezembro, 2020, de http://dx.doi.org/10.18764/2446-6549.e202032

\section{(c) commons}

This is an open access article under the CC BY Creative Commons 4.0 license.

Copyright (C) 2020, Universidade Federal do Maranhão.

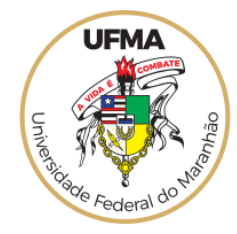

